\title{
6 Money and image: the presence of the state on the routes of economy
}

TONIO HÖLSCHER

\section{Introduction}

Coined money was invented and introduced in the seventh century BC by the Lydians, a small people at the edge of Greek culture. They first created a currency of so-called electron, an alloy of gold and silver, mainly for local circulation within Western Asia Minor. From the sixth century в с, however, coinage as a means of economic exchange, mostly in silver, rarely in gold, was increasingly introduced by various Greek city-states in Asia Minor as well as in Central Greece, and soon afterwards also among the daughter cities of Western Greece, in Sicily and Southern Italy. After its preliminary stage in Lydia, it was in the Greek world that coined money became the basis of economy in its most important aspects: payment and exchange, storing wealth, and measuring value. Late archaic Greece was the first society with a considerably monetized economy. ${ }^{1}$

The surprising fact about the origins of coined money is that they occurred not in one of the great empires of Mesopotamia or Egypt, with their monarchical structures and their unparalleled political and economic dominance, but in relatively small city-states without any firmly centralized political power. As is well known, in these so-called poleis there were neither firmly established rulers nor powerful priests who might have organized centralized economic structures, but a changing number of competing aristocratic families and an increasingly self-confident middle class, the members of which seem to have been concerned mainly with the micro-economic issues of their

${ }^{1}$ General introduction to Greek and Roman coinage: C. Howgego, Ancient History from Coins, London: Routledge 1995; S. von Reden, Money in Classical Antiquity, Cambridge University Press 2010. For a general theory of money, see the monumental work of K.-H. Brodbeck, Die Herrschaft des Geldes, Darmstadt: Wissenschaftliche Buchgesellschaft 2009. Iowe this reference to Ulrich Duchrow. 
market, common festivals, etc., and on the other hand the polis sanctuaries, serving communitarian religious rituals. In the old cities of the Greek mother-country the urban layout was determined by long periods of irregular growth, but the structural development, with an agora and one or more city sanctuaries, corresponded precisely with the "colonies". This structure can be defined as an egalitarian and reciprocally communicative system. ${ }^{4}$

The typical form of economy in the first phase of polis culture, through the ninth to seventh centuries $\mathrm{BC}$, was exchange trade and gift. $^{5}$ There existed some general value units, like cattle or bronze tripods, and some pre-monetary means of pay, like iron spits (obeloi) or silver bullion, ${ }^{6}$ but their adoption must, have been difficult in differentiated mercantile activities: they cannot have helped much more than to supplement and rationalize the prevailing practice of exchange. A crucial precondition in economic exchange was the basic incompatibility of commodities and services: a fisherman who needs a boat acquires at one moment a precious object for which he can pay only later, and only in small quantities, with his daily yield of fish. In this sense, exchange trade is fundamentally asymmetrical, with short-term services on the one side and long-term obligations on the other. As a consequence, it is based strongly on personal reliability and mutual trust.

A specific form of economic exchange, typical of this phase, was gift and counter-gift. Gifts were given, and answered by counter-gifts, among the dominant chiefs as the basic symbols of long-term relations. This practice, too, was not based on one-to-one equivalence, but was

${ }^{4}$ For the urban structure of early poleis, see R. Martin, L'urbanisme dans la Grèce antique, Paris: Oicard 1956, 75-96; E. Greco and M. Torelli, Storia

dell'urbanistica: Il mondo Greco, Roma-Bari: Laterza 1983, 65-148; T. Hölscher, Öffentliche Räume in frühen griechischen Städte, 2nd edn., Heidelberg: Winter 1998; D. Mertens, Städte und Bauten der Westgriechen, Munich: Hirmer 2006.

5 See recently von Reden, Exchange in Ancient Greece; B. Wagner-Hasel, Der Stoff der Gaben: Kultur und Politik des Schenkens und Tauschens im archaischen Griechenland, Frankfurt: Campus 2000, esp. 27-76 with a critical assessment of theories of gift.

6 Pre-monetary "media": I. Strøm, "Obeloi of Pre- or Proto-monetary Value in Greek Sanctuaries," in: T. Linders and B. Alroth, Economics of Cult in the Ancient Greek World, Proceedings of the Uppsala Symposium 1990, Uppsala: Gustavianum 1992, 41-50; Seaford, Money and the Early Greek Mind, 102-24; Thesaurus Cultus et Rituum Antiquorum V, 2.b (2005) 329-33 (S. Th.

Schipporeit). 
embedded in a comprehensive social system of dominance and dependence, in which the folks provided their lord with supplies and commodities, while the lord offered protection and justice to his followers. Exchange, therefore, was not immediate and piece-for-piece, but was a long-term interaction belonging to a système de prestations totales. ${ }^{7}$

National economists like Karl Bücher, social historians like Marcel Mauss and Louis Gernet, classical historians like Moses I. Finley, recently followed by Sitta von Reden and Beate Wagner-Hasel, have insisted on this "embedded" social character of gift culture and exchange trade and the deeply rooted fiduciary and moral aspects of this system. ${ }^{8}$

On principle, the relationship of long-term exchange and mutual support was also the basis of the interrelation between gods and mortal men. Here, too, the gifts of men, veneration through rituals and sacrifices, and those of the gods, such as welfare, richness, and success, did not result from one-to-one negotiations; the traditional principle of " $d o$ ut des" was no trade transaction of goods, but was a reciprocal establishment of long-term confidence and support.

A second phase of the archaic Greek polis, beginning in the decades around $600 \mathrm{BC}$, was marked by an increasing consolidation of the entire body of citizens, in which the prosperous middle classes played an essential role. The main concern was to integrate the mighty aristocratic leaders politically and mentally into the citizens' community, through efficient legislation based on reflection on the ethical and religious foundations of the polis. The effect was a considerable increase in civic coherence. It was in this period that the exigencies of economy within the community as well as the collective tasks of the citizen-body became more and more complex. However, there was no "state" institution, whether an individual monarch or a collective steering group, that had the power of organizing the community's economy. In the Bronze Age palace systems the ruler had assumed the function of organizing the economic preconditions of great collective activities.

7 M. Mauss, The Gift: The Form and Reason for Exchange in Archaic Societies, trans. W. D. Halls, New York: W. W. Norton 1990 (orig. pub. 1925).

${ }^{8}$ K. Bücher, Die Entstehung der Volkswirtschaft I, Tübingen: Laupp 1893; M. Mauss, "Essay sur le don: Forme et raison de l'échange dans les sociétés archaiques," in: L'année sociologique n.s. 1 (1923/24) 30-196; M. I. Finley, The Ancient Economy, London: Chatto \& Windus 1973; Wagner-Hasel, Der Stoff der Gaben, esp. 27-76. 
Now, in the developed polis of the late seventh and early sixth centuries, there emerged again great challenging exigencies and tasks - for which, however, the structures of the polis state were insufficient. In this situation, new forms of economy were required.

The gradual development of "money" in seventh- and sixth-century Greece corresponds precisely to this new stage of social and economic life. The pre-monetary means of paying that hitherto were in use had a practical function as well as a symbolic significance which determined their value: cattle were the primary riches of agrarian societies; bronze tripods and iron spits might be adopted as cooking vessels and roasting instruments for meat at religious festivals; bullion of precious metal could be melted down and used for various purposes. There was not yet a difference between exchange of goods and payment of value.

The first issues of stamped coinage, the Lydian electron coins of the seventh and early sixth centuries BC, still seem to have been used in a sort of gift system, in "an intermediate stage between 'pure' exchange of goods and the development of all-purpose money". "Monetization of the market in its proper sense was only - partly - achieved in sixthcentury Greece. Even then, money economy did not replace the practice of exchange trade, but complemented the traditional system. Nevertheless, the new currency implied a historical change of great impact.

\section{The immediate aims in the introduction of coined money}

The decisive new step of coined money was that the state created an artificial system of economic exchange. Recent approaches to this phenomenon see the principal goal of this initiative in the aim of "the polis" to promote commerce and to control the economy: ${ }^{10}$ the community of the middle classes, as the core of the citizen-body, is conceived of as the initiator of an egalitarian system of short-term exchange by which the traditional elite system of long-term gift exchange was efficiently fought

9 Price, "Thoughts on the Beginnings of Coinage," 5-8; Kurke, Coins, Bodies, Games, and Gold, 10 (quotation); Papadopoulos, "Minting Identity: Coinage, Ideology and the Economics of Colonization in Akhaian Magna Graecia," 41-2.

10 See (critically) Cook, "Speculations on the Origins of Coinage," 259: "Most Classical students assume that coinage was invented to assist commerce". Contra, e.g. Kraay, "Hoards, Small Change and the Origin of Coinage." 
against and ultimately superseded. ${ }^{11}$ In this sense, "coinage as a recompense" is thought to have become a symbol of "the polis as an institution that controlled justice and prosperity". And the traditional system of gift exchange, based on agrarian wealth and ancestral treasure, is seen as a concept referring to "a divine order of justice", favoring the mighty clan leaders in their privileged positions, while "the introduction of coinage indicates a shift of authority over social justice from the gods to the polis". 12

All this may in a higher sense be true. But it is difficult to imagine that such theoretical considerations corresponded to the explicit discourses and intentions of archaic Greek statesmen and citizens. Probably the introduction of coined money is one of the most striking cases of discrepancy between the concrete intentions of historical actors and the implicit consequences of their action. Both of these phenomena are highly relevant, but they should be kept and considered apart.

The state's "promotion of economy" seems to be a rather abstract and anachronistic concept of economic theory: who, in this period, is the "state" that exerts control? What is "the economy" that is to be promoted? In which way is this "control" conceived? And for what immediate purpose? It seems rather improbable that general concepts of "trade" and "market" were already in existence, and that specific structural measures were taken, aiming at steering "the economy". ${ }^{13}$ As soon as one tries to substantiate such explanations, difficulties arise. On the one hand, trade with external partners does not seem to have been of primary importance for the introduction of a money economy. ${ }^{14}$ Far-distance trade had already been effectuated in similar dimensions in the Bronze Age and again increasingly since the early Iron Age - without coined money. Carthage, with its powerful trade activities, did not coin money until the late classical period. In Greece, after the introduction of coinage, circulation was more-or-less confined to the issuing polis territory. Only in a few mighty poleis, like

11 Kurke, Coins, Bodies, Games, and Gold, 19-22; Papadopoulos, "Minting Identity: Coinage, Ideology and the Economics of Colonization in Akhaian Magna Graecia," 42-3.

12 von Reden, Exchange in Ancient Greece, 175.

13 On the absence of an abstract concept of "market" see Finley, The Ancient Economy, esp. 17-34.

14 Kraay, "Hoards, Small Change and the Origin of Coinage," 76-85; Papadopoulos, "Minting Identity: Coinage, Ideology and the Economics of Colonization in Akhaian Magna Graecia," 40-1: 
Athens, and to some degree Aigina and Corinth, did far-distance trade develop more and more, and the distribution of their coins testifies impressively how much this was facilitated by the new currency. But this was not the normal case. Therefore, the first motivation for the introduction of a money economy must be sought in new internal developments and exigencies of the polis. Promotion of "trade" in general can hardly have been a major concern of those who introduced coined money.

Regarding the practical use of coinage, it has often been assumed that the denominations of early Greek coinage were too high for retail trade in local markets. Recent research, however, seems to suggest the existence of rather substantial quantities of fractional coinage. Thus, the use of coins in individual economic practice cannot be excluded. ${ }^{15}$

Further questions arise regarding social and political explanations of coinage as an economic tool in favor of justice regarding the middle classes: did anybody intend or realize a direct connection between coinage and justice? Moreover, could anybody think of the possibility of shifting the authority of social justice away from the gods? Why, then, the overwhelming presence of divine images on Greek coins? Thus, if the aforementioned interpretations imply some higher truth, they probably do not correspond to the explicit intentions and aims but, rather, mark the inherent consequences and theoretical implications of early Greek money economy. Equally problematic are explanations of the introduction of money as expressions of a city-state's sovereignty, autonomy, and identity. ${ }^{16}$ Apart from the question why so many citystates for a long time did without this means of self-assertion, it is difficult to imagine that a polis changed its entire economic behaviour out of a purely symbolic motivation. Thus, before reflecting on such abstract second-level issues, some simple considerations seem to be appropriate.

The basic goal of the introduction of coined money was probably much more concrete and circumscribed; for the "state" had not only a monopoly in issuing money and in controlling and granting its value, but must above all have been the first distributor and "user" of the new currency. Thus, obviously, the introduction of coined money must have served the exigencies of a new kind of public enterprise and expenses

15 Howgego, Ancient History from Coins, 6-8.

16 Thus Finley, The Ancient Economy, 166. Contra: Martin, "Why did the Greek Polis originally Need Coins?" 259-64. 
which could no longer easily be fulfilled by the pre-monetary means of exchange. Since the first currencies, even in their smallest units, consist of relatively high values, coins must have served to recompense some precious commodity or long-term service. Because of their occasional application, coins seem not to have been issued with continuous regularity, but in response to specific needs. ${ }^{17}$

Early Greek city-states fulfilled only few tasks for which public recompense of major volume had to be paid. ${ }^{18}$ Political and sacred administration was accomplished by members of the wealthy classes, equipment for the citizen's army had to be provided by the citizens themselves, while the employment of mercenaries was a restricted practice in a restricted number of city-states. ${ }^{19}$ Higher state expenses regarding warfare were probably needed for warships, the costs of which must have exceeded the possibility of private financing. Doubtless, however, the most expensive field of state projects was public building. Indeed, it was in the period of the late seventh and the sixth centuries BC that Greek cities were transformed through new devices of urban monumentalization: the civic centres (agorai) were enlarged and equipped with public buildings, the main streets were paved, abundant water supply with pipelines was provided and water-houses were built, drainage systems were constructed, the urban settlements were encircled with mighty city walls. And above all, the great polis sanctuaries were provided with monumental and richly adorned temples, altars, porticoes, banquet halls, entrance buildings, some of them also with installations for athletic training and competition. ${ }^{20}$ Such constructions were

17 Kraay, "Hoards, Small Change and the Origin of Coinage," 320-8.

18 On financial practice and purposes of coinage in archaic Greek city-states, see C. Starr, The Economic and Social Growth of Early Greece 800-500 B.C., New York: Oxford University Press 1977, esp. 97-117; Martin, "Why did the Greek Polis originally Need Coins?"

19

Hiring mercenaries as the purpose of early Lydian electron coinage: Cook, "Speculations on the Origins of Coinage," 259-61. The examples of state financing of warfare cited by C. M. Kraay, "Greek Coinage and War," in: W. Heckel and R. Sullivan (eds.), Ancient Coins of the Graeco-Roman World: The Nickle Numismatic Papers, Ontario: Wilfried Laurier University Press 1984, $3-18$, are all post-archaic.

${ }^{20}$ In this sense, see Starr, The Economic and Social Growth of Early Greece 800-500 B.C., 113; Martin, "Why did the Greek Polis originally Need Coins?" 267-72. See also Seaford, Money and the Early Greek Mind, 75-87. In general on money in religious contexts, see von Reden, "Monetary Economy in the Greek World,” in: Thesaurus Cultus et Rituum Antiquorum vol. VIII (2012), 11-127. 
designed for the consolidated civic communities of this period, and they served public purposes which afforded additional financing by the polis: in particular, the great religious festivals with athletic and musical competitions, sacrifices, public meals and banquets which, besides the irregular efforts of building projects, constituted a high regular burden.

For all such projects, storage of financial resources and continuous payment to large numbers of workmen was necessary. In this regard, the traditional exchange economy did not constitute a sufficient basis; minted coinage was much better suited to fulfill these needs.

Precise chronological correspondence between the origins of coinage and urban monumentalization in stone is difficult to prove. Firstly, the emergence of monumental architecture occurred gradually, not in a definite step towards a higher level of monumentality; in addition, there are few cities where investigations give a comprehensive insight into this development. Within this change of urban centres there is no moment when the introduction of coined money became "necessary": we can only determine periods when coining money became a plausible solution to increasing problems. On the other hand, dates of the origins of coining within the various Greek cities are still, within certain limits, controversial among numismatists.

With these precautions, some figures may be given as a framework for substantiating the interrelation between sacred architecture and coinage:

\begin{tabular}{|c|c|c|}
\hline & Coinage & Temples \\
\hline Ephesos & 600 в (electron), 540 в С & 560 в С \\
\hline Samos & 7th century (electron), 530 в С & $570-560$ в С \\
\hline Miletos & $600-575$ в (electron) & 550 в С (Didyma) \\
\hline Athens & $570-550$ в с & $580-560$ в С \\
\hline Aigina & $580-560$ в С & 570 в С \\
\hline Corinth & $570-550$ в С & 540 в С \\
\hline Taras/Tarentum & 500 в С & 560 в С \\
\hline Metapontion & 550 в & $570-560$ в с \\
\hline Poseidonia & 530 в С & 540 в С \\
\hline Syracuse & 530 в С & 580 в С \\
\hline Akragas & $520-510$ в с & 530 (?) в C \\
\hline Selinunt & 520 в С & $560-540$ в С \\
\hline
\end{tabular}


Obviously, in some places like Aigina, Corinth, or Athens, the origins of coinage occurred roughly at the same time or slightly earlier than monumental temple building; in Eastern Greek places like Ephesos, Samos, and Miletos, the monetary conditions had already existed for some decades, while in Western Greece cities like Taras, Syracuse, or Selinus started monumental temple building without coined money, and only later seem to have felt the need for supporting their great building programs with coinage of their own. All this, however, does not contradict the general interrelation between coinage and monumental urbanization, of which temple building was only one of several factors.

Generally speaking, not only was the society of the polis state a higher, second-level community, but also the common exigencies and tasks changed from the production for individual persons and families to the enterprises of and for the whole community.

Contrary to the great centralizing monarchies of ancient Mesopotamia and Egypt, with their powerful system of collecting and redistributing material goods, early Greek cities did not have a sufficient economic infrastructure in order to accomplish public enterprises of such dimensions. While formerly, individual craftsmen or workshops, busy with short-term production, were remunerated by individual customers, now the community had to pay great numbers of workmen for more-or-less long-term work. Remuneration in commodities would by far have exceeded the capacities of early Greek poleis with their yearly changing non-professional magistrates. To cope with such problems, a means was created by which the property of the community could be accumulated, stored and paid out in small units to individual persons according to their individual quantity of labour. Thus, it was the specific lack of political power and the infrastructural weakness of Greek poleis that was the basis of the introduction of a money economy. Instead of the powerful organization of redistribution, a slim system of "abstract" payment was installed. On the other hand, this makes it clear why a money economy did not spread out through the Near East and Egypt: there, under the conditions of hierarchical monarchic power, public labor and exchange were differently organized; there was no market in which free convertibility of coined money was needed.

For the recipients, payment by money must soon have become attractive. Whereas in the traditional exchange and gift culture the recompense 
depended on the specific goods that one's partner could offer, money was a completely abstract potential, allowing conversion of labor or commodities into all kinds of goods, in any place and at any time. Thereby, the bonds and dependencies between patron and employee, buyer and seller, became looser. Money was - for those who disposed of it - a vehicle of social autonomy.

It may be doubted, however, whether coined money was conceived of as a weapon in the struggle of the middle classes against the traditional elite. For it seems to be a rather modern and theoretical idea that this struggle was consciously and intentionally fought as a battle of economic systems. In fact, if one of the basic functions of coined money is its capacity for storing wealth, then this new economic instrument served the purposes of the prosperous elite very well. On the whole, the leading classes were always successful in adapting themselves to new social and economic situations, exploiting new means of cultural practice, putting themselves at the head of new developments, and thereby maintaining, defending and even strengthening their social position. They will have played a leading role in the introduction of coined money.

Compared with pre-monetary objects of value, like tripods or spits, not to speak of cattle, coined money had several advantages. It consisted of precious metal, rarely gold, mostly silver, both of which had hitherto been an exclusive exchange property of the elite: this must have granted a certain confidence in the new currency. But unlike pieces of metal, which were necessarily of uncertain weight and purity and had to be controlled in every transaction, coins were given a standardized form and a conventional value. This change from intrinsic to socially conferred values was the decisive phenomenon in the genesis of money.

The value of coins lay somewhat above bullion value, which means that it was fixed by convention. ${ }^{21}$ This was on the one hand an advantage, since it prevented coins from being converted into bullion. On the other hand, however, this must have created problems, since for their reduced metal value their recognition was at risk: therefore, the convention of coins' value had to be guaranteed by some "public" authority. If certain goods or labors were to be paid with coins, this

21 See J.H. Kroll, “Silver in Solon's Law,” in: R. Ashton and S. Hurter (eds.), Studies in Greek Numismatics in Memory of Martin Jessop Price, London: SPINK 1998, 231. 
presupposes a market, accessible to everybody, where the acceptance of coins was granted and where coined money could be converted into commodities for everyday life. How was collective confidence to be achieved in a value which so evidently was based on pure convention? The crucial point in this cannot have been the purity and the weight of the metal, since this was difficult to control (and moreover would have made the grant useless), but the certainty that the coin would be taken back by the issuing authority. Here again, the institutional weakness of Greek city-states turned out to be a strength. In the absence of strong central powers like monarchies or mighty priesthoods, there was no independent authority which could grant the value of coinage to the community of its users - except the community itself. It is the community of citizens that assures itself and others of the validity of its coins, by images and inscription, typically in the genitive plural: e.g. (coin) "of the Syracusians". Paradoxically, this is precisely where the force of the whole concept seems to lie: since it was the same community that on the one hand fixed and on the other hand acknowledged and accepted the coinages' value, this was a highly stable system.

In this sense, the introduction of coinage, first of all, served civic communities to accomplish their communitarian enterprises and to facilitate their economic communication, in particular within their own realm, but also beyond in economically dynamic city-states. It was the result of a far-reaching process of depersonalization and decentralization, by which all participants of economic transactions were freed from hierarchically imposed authorities and long-term dependencies, through which they became equal partners, acting in immediate independent exchange. The trustworthiness of this system was based on a high degree of social coherence and reciprocity, insofar as coined money was an important step towards and a firm element of an egalitarian civic society.

Roots of this kind of community sense have been convincingly seen in sacrificial rituals. ${ }^{22}$ Sacrificial meals at the great polis festivals were occasions of egalitarian division of meat among all citizens, who constituted the polis' central sacrificial community. Such sacrifices had to be paid for by the community, with equal contributions, which then were converted into equal distributions. For that purpose, too, a currency of equal units was very useful. That the origins of money are indeed

22 Seaford, Money and the Early Greek Mind, 48-67. 
connected with the sphere of sacrifice becomes clear from the name of the most common coin, obolos, originally meaning the spit used for sacrificial meat consumption. Indeed, the great political reformer and poet Solon, who fixed the sacrificial calendar of his mother-city Athens, also determined prices of victims for public sacrifices. Thus, sacrifice seems to have been "an early agent of monetization". ${ }^{23}$ From these origins, temples became the main places for storage of a city's treasures. An impressive inscription from the temple of Artemis at Ephesos records silver and gold coming from various sources: "from the polis", "from the wood", "from here", "from the naval", "from the salt", etc. ${ }^{24}$ Thus, temples became places of egalitarian, communal distribution for religious, political and other communitarian purposes.

Even more, and to an amazing degree, the fully developed democracy of classical Athens was based on money: law courts in which thousands of members were involved every day, citizens' assemblies which gathered on average every ninth day, and many other institutions were paid in order to make participation possible for all citizens.

In this sense, Plato and Aristotle consider trade and money fundaments of communitarian life. Money makes things commensurable and thus promotes exchange and community, koinonia. ${ }^{25}$

This community, at least in its first phases, above all was the community of the individual polis citizens. As we saw, coins were first primarily designed and used for payment and exchange within the issuing state's territory. This was enhanced by the fact that many cities used their own weight standards, which must have considerably impeded conversion. On the other hand, this fact must have led to the result that the citizens considered "their" coinage as their own property. It was their collective good, and it was their own responsibility that granted this good's reliability and stability. In fact - if we don't ask for specific intentions but for general implications - coinage could become a sign of the city's self-assertion and a symbol of its identity. Not as a political propaganda message, but as a sign of the community's richness, distributed and floating among individual owners.

23 Seaford, Money and the Early Greek Mind, 75-87; R. Parker, Athenian Religion, Oxford: Clarendon Press 1996, 43-55; Kroll, “Silver in Solon's Law,” 225-32.

24 Inschriften von Ephesos I (1979), Nr. 1.

25 Plato, Republic 371b; Aristotle, Nicomachean Ethics 1133b. 


\section{Structural implications}

Beyond the immediate intentions and purposes of the introduction of coined money there occurred some basic structural changes inherent in the process of monetization in early Greece which cannot, from the beginning and in every respect, have been obvious to its participants, but became implicitly efficient in the course of time. In the form of coinage, the accumulation of wealth tended to become an end in itself, independent of former social interrelations. Certainly, this is not a substantialistic quality of coinage as such, implying necessary consequences in social behavior. ${ }^{26}$ Like all cultural goods, coined money attained its significance via changing cultural practice: on the one hand money could be used to create and ensure social connections, and on the other hand the accumulation of wealth could also become an autonomous practice without, and before the introduction of, coinage. Nevertheless, coined money had some qualities and aspects that might at least have served such tendencies. ${ }^{27}$

Whereas the traditional exchange of goods and gifts had been a specific act, confined to specific occasions, effectuated through specific objects with specific symbolic meanings for specific purposes, particularly for creating personal bonds and relations between the donor and the receiver of the object, money more-or-less excluded such symbolic values. Exchange on the basis of money was universal: money had no special purpose, it could be applied to all things, to all subjects, in all contexts. Consciously or unconsciously, this was in various respects a far-reaching process of abstraction.

First: Transactions on a monetary basis tended to be basically non-personal: whereas gifts are personal acts directed to personal addressees, commodities may be bought from and sold to anyone. Gifts, being not immediately compensated by counter-gifts, create long-term obligations; goods, being exchanged on the basis of trustworthiness, presuppose long-term relations; while acquisition by and sale for money do not create any specific relationship between the

26 This is particularly stressed by von Reden, Exchange in Ancient Greece, 171-216. See also Papadopoulos, "Minting Identify: Coinage, Ideology and the Economics of Colonization in Akhaian Magna Graecia,” 39.

27 With what follows, compare Seaford, Money and the Early Greek Mind, 147-72, with substantialistic tendencies. 
respective actors - on the contrary, payment by money, as an immediate compensation of a debt, terminates any such interrelation.

Second: Whereas the exchange of gifts is effectuated with things and activities of specific cultural or psychological valor, money does not allow for measuring the price of things that are at one's heart or have a personal significance - on the contrary, money constitutes a measure that applies to all objects and actions of human life alike. The most varied of things are deprived of their specific emotional or symbolic qualities and character by measuring and evaluating them according to their monetary value.

Third: This reduction and neutralization of individual persons to subjects and of things to objects is made possible by a general and neutral measure of value. Representing conventionally fixed values, and therefore being of no concrete use, money is the clearest expression, and at the same time the most effective promoter, of a specific kind of abstract thinking - which concerns not only the economy, but the whole society with its specific concepts of man, social values, and social interaction.

Fourth: A decisive new step consisted in extrapolating this value from the objects into a medium of its own. Whereas formerly value was inherent in valuable objects, now it became an autonomous system. This does not mean to deny preliminary stages of this development, e.g. silver bullion or spits used as currency; but it was only in the form of coined money that "value" became a system with its own, self-regulating rules. In principle, this has not changed even in the present development towards a moneyless credit economy where mere numbers like the Dax or the Dow Jones have taken over the function of an autonomous value system. Anyway, this is the precondition under which money could be valued as an autonomous factor of social development and social crisis.

Without any doubt, the introduction of coinage was a great intellectual and cultural achievement. As we have seen, a similar kind of rational thinking underlies the design of newly founded cities and their territories. Moreover, as has been acutely observed, pre-Socratic philosophy, with its reduction of the multiplicity of existing things to a unique principle, like water, corresponds closely with the abstract concept underlying the monetization of early Greek economy. ${ }^{28}$ 
Homogenization of persons and objects, universality and pervasiveness of coins and money: these were achievements that could be conceived, and were in fact evaluated, as progress towards social equality, justice, and free communication. However, as we shall see, the same phenomena also became the goals of sharp criticism.

An unconscious consequence of this development was the fact that the exchange of goods among men became fundamentally different from the exchange of reciprocal support between men and gods. Whereas the religious relationship of mortal men to their gods remained a long-term connection based on the principle of gift exchange, veneration and benevolence, the market of money-based trade and shortterm exchange obeyed totally different rules which essentially belonged to the human world. It is true that some Greek sanctuaries, with their accumulating wealth, adopted functions of banking on a monetary basis; but these economic activities were a game with different rules than the religious interactions between men and gods through traditional votive-offerings.

\section{Images}

A specific quality of coins, which in antiquity was exploited even more than today, resulted from the combination of two of its features.

First: Coins were authorized by political units, states or rulers; they embodied their authorities, in a sense. This becomes particularly obvious in the marks of authentication they are distinguished by. The authority that issued money as today, made itself "present" on its coins, by inscriptions and images. Such images are highly interesting testimonies of how ancient cities and states aimed to present themselves within their own realms as well as towards the external world. These are images of political identity.

Second: Coins were an official medium with the widest diffusion conceivable. The routes of internal exchange and external trade became routes of coins, and by implication, routes of presence of those states by which these coins had been issued. In a world without mass media, coins were a uniquely ubiquitous means of official self-presentation through images.

The choice of a motif of "identity" implied two perspectives: towards the interior and towards the exterior. Regarding the home city, a motif had to be found that was acknowledged by the whole community; 
regarding the surrounding world, this motif had to define the home city in relation to other cities, either by distinction or by assimilation.

\section{Archaic and classical Greek city-states}

The first phase of Greek coin issuing was shaped by the competitive situation within and among the countless larger and smaller city-states. Images, being the most conspicuous features of coins, were used on the one hand in order to visualize an individual polis identity, and on the other to signal distinction as well as interconnections among various city-states.

Most cities relied on gods to whom they reserved the obverse side of their coins, while the reverse side was often decorated by some other characteristic motif, symbol, or other. On principle, this must have been intended to put the city's money under divine protection. How these decisions were taken can only be guessed at. In Athens the choice of the city's name-goddess Athena on the obverse and of the goddess's owl on the reverse was probably uncontroversial. Normally, however, Greek cities had not one major "city-god(dess)" but many gods and goddesses of public importance; therefore they had to decide to which god they were to entrust their money. In Syracuse, for example, Apollo and Athena had old temples in the city centre; for what reason the local nymph-goddess Arethusa was chosen to adorn the city's lavish coins - perhaps as a compromise between different groups - is a matter of pure speculation. ${ }^{29}$

Other cities had symbols of their wealth on their coins: thus, Sybaris issued with a bull and Metapontion with a corn-ear, documenting agricultural richness, while Kroton had a tripod, perhaps indicating access to mineral resources and metal industry. ${ }^{30}$ But again, we will never know how much these motifs were contested by groups other than the rich landowners or metal merchants.

Besides the city's internal identity, there were the relations to the surrounding world. ${ }^{31} \mathrm{~A}$ city might choose a deity who was present on an allied city's coins, thus expressing positive political relations; or a

${ }^{29}$ See the complicated explanation given by E. Boehringer, Die Münzen von Syrakus, Berlin: Walter de Gruyter 1929, 95-102.

30 Papadopoulos, Money and the Early Greek Mind, 28-39, with whom, however, I do not agree regarding possible references to Bronze Age traditions.

31 S. Ritter, Bildkontakte: Götter und Heroen in der Bildsprache griechischer Münzen des 4. Jahrhunderts v. Chr., Berlin: Reimer 2002. 
deity of an adversary city, indicating political opposition. Accordingly, the choice of the same deity could demonstrate alliance as well as opposition. Athens created for her coins a new type of Athena with an open, so-called "attic" helmet, while soon afterwards her great economic rival Corinth also chose Athena, but with a closed, so-called "Corinthian" helmet, pushed backwards over her forehead. That this is not a negligible detail is shown by the fact that later the Athenian daughter-city Thurioi and the Athenian ally Neapolis took over the Athenian version of Athena, while the Corinthian daughter-cities Leukas and Ambrakia followed the Corinthian version. Political affiliations were expressed through the assimilation of coin images. On the other hand, a blatant example of polemic reception is given by Syracuse, after the glorious defeat of the Athenian fleet (413 в ), through a new series of splendid silver coins where the traditional version of Arethusa is changed into a spectacular representation of Athena - with an Athenian-type helmet! Thus, the images of a city's gods or goddesses were received and imitated by political allies and friends, opposed by political rivals, and “occupied" by political enemies.

\section{Hellenistic monarchies}

The rulers of the great Hellenistic monarchies made extensive use of coins in order to make themselves "present" through their vast empires. Alexander the Great in many places of his realm, from Greece and Macedonia to Alexandria, Beirut and Babylon, installed highly efficient mints producing a unified currency, authorized in the king's name: silver coins with his alleged father, Zeus, on the obverse and his ancestor, Herakles, on the reverse, and gold coins with his tutelary goddess, Athena, and the victory goddess, Nike. This was probably Alexander's most far-reaching measure in order to unify his immense empire with its extremely heterogeneous political and cultural traditions: coined money allowed and encouraged boundless economic communication, and the coins' images testified to the ubiquitous "presence" of the ruler who granted the trustworthiness of material value. This communicative force of circulating coinage must have been particularly efficient in the newly conquered lands of the former Persian Empire, east from Asia Minor and Phoenicia, where coined money was hitherto practically unknown. Thus, the gods of the new ruler circulated on the coins in the contexts of new forms of trade. 
Alexander's successors, the rulers over the great empires of the Hellenistic age, even put their own images on the coins: these became the most obvious demonstration that the king, in the form of "his" money, was efficiently present in all parts of his realm and permeated the life of all his subjects.

\section{Roman Republic}

These possibilities of coins were exploited to an extreme degree in ancient Rome. ${ }^{32}$ During the Roman Republic, images of gods and goddesses testify to the various goals images could serve. As a norm, coin values were distinguished by different gods: the denarius, the main coin, was marked by the goddess Roma, the quinarius by Hercules, the as by Ianus, and so forth. Thus, the system of coinage was visualized with a stable constellation of gods and goddesses. On principle, this multifaceted stability corresponded to the "system" of coin images of Hellenistic monarchies.

Nevertheless, when Roman armies conquered Greece and installed Roman rule from the second century B , this was not followed by an expansion of Roman money: ${ }^{33}$ finds of Roman coins from the period of the republic are rare in Greece. This does not imply that Rome did not interfere in the economic system of the conquered East. The first victorious general, T. Quinctius Flamininus, probably stopped the circulation of coins of Macedonia, Rome's immediate enemy, but a little later Rome accepted and promoted a powerful local coinage, the Athenian "new style silver coins". A similar situation is to be observed in other parts of the Eastern Mediterranean that had come under Roman rule. And even in Spain where the use of coinage had formerly been very restricted, the Roman conquest of the second century в $\mathrm{B} \mathrm{did} \mathrm{not} \mathrm{entail} \mathrm{a}$ wide diffusion of Roman money; towards the middle of the century, Rome even initiated a local coinage, based on the Roman weight system, but with local images. Obviously, the truly Roman denarius and as system, with its characteristic imagery, was mainly destined for circulation and comprehension within the realm of the capital and Italy.

32 The whole repertoire is readily accessible, with commentaries, in

M. H. Crawford, Roman Republican Coinage, Cambridge University Press 1974.

33

M. H. Crawford, Coinage and Money under the Roman Republic, London:

Methuen 1985, 116-32. 
During the last century of the Roman Republic, this relatively stable system of coin images was rapidly changed into an extremely flexible instrument for political messages. ${ }^{34}$ The struggle of mighty army commanders for political power and the ensuing competition for social prestige within the upper classes resulted in an increasing public demonstration of personal claims and achievements in all realms of life. For this purpose, coins were a particularly efficient medium. Although the office of the three magistrates responsible for coin issuing was a rather low rung at the beginning of a political career, moneyers used coins for highly specific political messages: either promoting their own interests and careers, by depictions of their political activities, legislation, organization of public games, erecting public buildings, and so forth; or by glorifying and supporting one of the great protagonists of political life, the triumph of Marius, or the symbols of charismatic world-rule of Julius Caesar. To this end, a most complex imagery of political themes, allegories, and symbols was created, through which coins became a medium of a widely dispersed political discourse. Finally, Julius Caesar was given the right to put his own portrait on his coins, as Hellenistic kings used to do.

Scholars like to speak of this practice as "propaganda" - which, however, implies some misleading connotations. The images as such are in part not very clear, difficult to understand, and therefore lacking the self-explaining evidence and convincing power that is to be expected from "propaganda". And regarding the users of money, one may doubt whether they normally studied coin images with such intensity that they might be influenced by them in their political positions. More adequate are the notions of "self-assertion" and "claim". Impressing one's own figurative motif and script on the public medium of coinage means to occupy this medium for a symbol of one's own person and thus imposing one's own claims by forcing the community to acknowledge this

34 A. Alföldi, "The Main Aspects of Political Propaganda on the Coinage of the Roman Republic," in: R. A. G. Carson and C. H. V. Sutherland (eds.), Essays in Roman Coinage presented to Harold Mattingly, Oxford University Press 1956, 63-95; Crawford, Coinage and Money under the Roman Republic, 712-44; T. Hölscher, "Die Bedeutung der Münzen für das Verständnis der politischen Repräsentationskunst der späten römischen Republik,” in: T. Hackens and R. Weiller (eds.), Actes du 9ème congrès international de numismatique, Bern 1979, Louvain-la-Neuve: Association Internationale des Numismates Professionels 1982, 269-82. 
self-assertion. In this sense, the distribution of coinage within the political community makes these images and their implied claims universally present.

\section{Roman Empire}

The Roman emperors monopolized this unique medium of political publicity. With great iconographic skill whole programs were displayed, changing according to the vicissitudes of historical events and the ideological and mental moves of the time: the emperor's heroic feats, in particular military campaigns and triumphs; his significant political acts, like public sacrifices, distribution of money, speeches to the army; personifications of his ideological issues, like Virtus, Pietas, Concordia, Fides, Felicitas, and so forth. By this example, coins became a most manifold panel of imperial policy. ${ }^{35}$

Even here the term of "political propaganda" is misleading. Certainly, there was no central institution for steering public opinions; nor was there any aim of ideological infiltration in the sense of Christian mission (from where the term "propaganda" is derived: propaganda fide) or even of modern dictatorial regimes, addressing potential opponents. More appropriately, we might speak of panegyric exaltation aiming at creating an atmosphere of general consent. Much more interesting, however, and highly debated, is the problem of the efficiency of this medium. Were coins intensely observed? Were their messages eagerly received, enthusiastically or critically interpreted and commented on? By whom? With what results? Leading to what kind of reactions? All this would be a matter of high-level theory about lowlevel political communication, which is an important task for future interdisciplinary research between art history, political science, and semiotics: a theory which would have to consider on the one hand the extraordinarily complex imagery of the emperor's and the state's political presence in this medium, and on the other hand the normal situations of low attention in this medium's use - but always keeping in mind that it must have been an efficient medium, as is testified by its endurance through the centuries.

35 Coins of the Roman Empire in the British Museum I (1923)-VI (1962);

C. H. V. Sutherland, Coinage in Roman Imperial Policy 31 B.C.-68 A.D.,

London: Methuen 1951. 


\section{The consequences of coined money in ancient judgments}

Ancient authors, critical authorities, as well as low-level observers and participants in economic life, were well aware of the great changes, in part revolutionary in part structural and processual, that were implied by the introduction of money: with consequences that not only concerned the economy, but in many respects deeply affected social, cultural, and even religious life, attitudes, and mentality.

Homer, the great representative poet of "heroic" values in a world of the emerging polis, marginalized the world of trade although this was one of the seminal factors of his time. Nevertheless, his hero, Achilleus, defends, in a symptomatic way, the values of his "self", his "psyche", against the tempting offers of wealth: when Agamemnon takes away his maiden who had been given to him as a reward for his bravery in battle and who thus was the sign of his time, his social excellence, he resisted all compensation, saying that no wealth could ever have so much value as his psyche, his personal "self". ${ }^{36}$

From that time, there emerges a broad tradition of far-reaching criticism of wealth in Greek literature, particularly of its universal and pervasive character, which undoubtedly implies coined money. ${ }^{37}$ This criticism is to be seen in the horizon of a society in which property was in fact the undisputed basis of social rank, even in the periods of the most radical form of Athenian democracy. Against this background, such criticism may seem at first sight somewhat hypocritical, but on the other hand it is this horizon which gives criticism of wealth its sharpness.

Money acquires everything. For money one can have beauty, health, noble birth (by paying the dowry for a noble bride), the favor of gods (by acquiring an expensive sacrifice victim), even human beings: prostitutes. Ares, the god of war, is a trader, exchanging even corpses for wealth. ${ }^{38}$ Thukydides is particularly bitter: "No currency ever grew up among humankind as evil as money: This lays waste even cities, this expels men from their homes, this thoroughly teaches and transforms good minds of mortals to set themselves to disgraceful acts; it showed men how to practice villainies and to know every act of impiety". ${ }^{39}$ And Sophocles concludes: money creates friends, honor, political power

${ }^{36}$ Homer, Iliad 9, $401 \mathrm{ff}$.

37 Seaford, Money and the Early Greek Mind, 147-72. ${ }^{38}$ Ibid., 157-65.

39 Aischylos, Agamemnon 438. 
near to tyranny, physical beauty, wise speech, and pleasure even in disease. ${ }^{40}$

As a consequence, money becomes a goal in itself. The acquisition of tripods has a natural limit set by their use (to boil meat, as gifts, etc.) and by the problem of storing them. Equally, according to Aristophanes, the purchase of all other goods - sex, bread, music, glory, warfare, and so forth - has an end in satiety. But money is accumulated without limits. ${ }^{41}$ While commodities are normally sold for money in order to acquire other commodities $(\mathrm{C}-\mathrm{M}-\mathrm{C})$, now money is invested in commodities in order to make more money $(\mathrm{M}-\mathrm{C}-\mathrm{M}-\mathrm{C}-\mathrm{M})$. And whereas the first of these sequences finds a natural end in the acquisition of the desired commodity, the second sequence is fundamentally unlimited.

Alkaios, the early archaic poet, already assured: "Man is wealth". ${ }^{42}$ Not much later, the poet Pythermos says: "All other things than gold were nothing”. ${ }^{43}$ Still more radically, Aristophanes concludes: Wealth "is the unique source of all things, good as well as bad". ${ }^{44}$

However, the position of Achilleus in Homer was not forgotten. Solon, who had already created a new class-system on the basis of property, insists that there are limits to the desirability of wealth. ${ }^{45}$ The myth of Midas who miraculously transformed everything he touched into gold, but almost starved to death because his food was transformed too, was a popular warning. The same Solon, when he was asked by Kroisos, the richest king of his age, about the happiest of men, is reported to have surprised his partner by not naming Kroisos because of his immense riches, but a certain Tellos of Athens who had lived in a prosperous city, was the father of noble sons, saw children born to all of them, and having had as much wealth as a man may "among us", crowned his life with glorious death in war for his fatherland, for which he was given the great honour of a public burial. ${ }^{46}$ This text is particularly interesting because it does not create a fundamental

40 Sophocles, frg. $88 . \quad{ }^{41}$ Aristophanes, Ploutos 189-97.

42 Alkaios, frg. 360.

43 Pythermos: D. L. Page, Poetae Melici Graeci, Oxford: Clarendon Press 1962, nr. 910.

44 Aristophanes, Ploutos 182. ${ }^{45}$ Solon, frg. 24.

${ }^{46}$ Herodotus 1, 30. On Tellos see also the interesting interpretation by L. Kurke, "The Economy of Kudos," in: C. Dougherty and L. Kurke (eds.), Cultural Poetics in Archaic Greece: Cult, Performance, Politics, New York: Oxford University Press 1998, 153f. 
antithesis between material riches and ethical values, but acknowledges moderate wealth, together with a thriving family, as a prerequisite of happiness; indeed, Tellos was a member of the Athenian upper class which defined its rank through its material property and its ensuing freedom from physical labor. But this wealth is neither excessive nor competitive, it keeps within the norms that prevail "among us". And, above all, as a measure of happiness it is superseded by merits for the fatherland, in opposition to the false self-evidence of material riches.

Later, in tragedy, it is frequently asserted which goods and values are never and under no condition to be submitted to the power of wealth and money: a trouble-free life, a good wife, a genuine friend, the fatherland, wisdom; on the other hand, essential goods cannot be acquired by money: youth, peace, virtue. ${ }^{47}$

\section{Conclusion}

From what we have seen, it becomes evident that Michael Welker's distinction between such commodities that may and should be submitted to the mechanisms of money and market, and such values that should be excluded from the dynamics economy, ${ }^{48}$ has explicit precedents in ancient Greece. There is no question that a certain measure of prosperity and property is a desirable fundamental of human happiness. But there are two basic limitations to accumulating riches: first, the acquisition of wealth should not become an end in itself, obeying only an autonomous market's rules; and second, wealth should not be acquired at the costs of essential goods and values of human societies and individuals.

From this, one might deduce a proposal for the problems of the present: a project of anthropological research on how much wealth an individual person can - anthropologically - use and exploit for his own and his relatives' physical subsistence and moreover for their physical,

47 Aischylos, Hiketidai 935; Persai 842; Euripides, Alkestis 56-9; Elektra 941; Herakles 643-8; Ion 629-31; Medeia 598-9; Phoinissai 552-4. Seaford, Money and the Early Greek Mind, 162, with further testimonies.

48 M. Welker, "Ab heute regiert Geld die Welt: Die Einführung der Geldwirtschaft und ihre Auswirkungen auf religiöses Denken und ethische Orientierung," in: C. Gestrich (ed.), Gott, Geld und Gabe, Berlin: Wichern Verlag 2004, 52-66. 
intellectual, and ethical pleasure. ${ }^{49}$ What should be opposed is the function of wealth as a symbol of social status, since this is the starting point of an abstract valuation of money as an end in itself. By such an investigation, it might be possible to fix a scientifically founded and socially acceptable maximum limit of personal wealth. If a project of this kind were installed by political authorities and realized by independent scholars of international renown, there might be a chance for transferring its results to the realm of public policy. Perhaps the authority of respectable ancient authors helps to make this proposal less naïve than it might appear to modern finance politicians.

${ }^{49}$ An attempt in this direction is made in the Report: Churches Addressing Greed: The Work of the Greed Line Study Group of the World Council of Churches (WCC), not yet available (draft made available to me by Ulrich Duchrow). 